This is a postprint/accepted version of the following published document:

Paz-Aparicio, C.; Ricart, Joan E.; Bonache, J. Understanding the decision to offshore human resource activities: a coevolutionary perspective. In: International journal of physical distribution \& logistics management, 47(2/3), March 2017, Pp. 175-197

DOI: https://doi.org/10.1108/IJPDLM-09-2015-0224

(C) Emerald Publishing Limited 


\title{
Understanding the decision to offshore human resource activities: a coevolutionary perspective
}

\author{
Carmen Paz-Aparicio \\ Department of Business Management, Universidad Carlos III de Madrid, \\ Madrid, Spain \\ Joan E. Ricart \\ Department of Strategy, IESE Business School, Barcelona, Spain, and \\ Jaime Bonache \\ Department of Business Management, Universidad Carlos III de Madrid, \\ Madrid, Spain
}

Received 19 September 2015

Revised 6 February 2016

23 June 2016

3 October 2016

26 October 2016

Accepted 26 October 2016

\begin{abstract}
Purpose - Offshoring has been studied widely in the literature on strategic management and international business. However, apart from its consideration as an administrative activity, scant attention has been paid to the offshoring of the human resource (HR) function. Research in this regard has instead focussed on outsourcing (Reichel and Lazarova, 2013). The purpose of this paper is to achieve a better understanding of companies' decisions to offshore HR activities. It adapts the outsourcing model of Baron and Kreps (1999) by including the HR offshoring phenomenon and a dynamic perspective.

Design/methodology/approach - While the analysis is mostly conceptual, the authors ground the author's arguments in offshoring data from the Offshoring Research Network, to explore whether the drivers for offshoring HR differ from the drivers for offshoring other administrative activities. The idiosyncrasy of the HR function is supported by the authors' exploratory analysis and also by the descriptive case of a multinational and its experience with offshoring.

Findings - A coevolutionary model is proposed for understanding the behaviour of companies offshoring their HR activities. This study contends that companies should address their decision to offshore HR activities from a dynamic perspective, being aware of three processes that are in constant change: the evolution of the $\mathrm{HR}$ function, the evolution of service providers, and the evolution of offshoring decisions.

Originality/value - This study seeks to make a threefold contribution to the international business, strategy, and HR management disciplines.
\end{abstract}

Keywords Outsourcing, Human resources, Offshoring, Drivers, Administrative activities,

Coevolutionary model

Paper type Research paper

\section{Introduction}

Offshoring has been and indeed still is being studied extensively in the field of strategic management (for a review, see Kedia and Mukherjee, 2009; Lewin, Massini, Perm-Ajchariyawong, Sappenfield and Walker, 2009; Pisani and Ricart, 2016). Offshoring, as well as outsourcing, have affected many administrative activities in the firm including HR management (Anderson, 2015; Demirbag et al., 2012; González-Loureiro et al., 2014). However, the particular nature of the HR function and its strategic value have not been included in a model helpful for decision making related to the phenomenon of the offshoring of this function.

Studies of the offshoring of service activities have taught us about some identifiable trends. The phenomenon started with offshoring very operative and transaction-oriented activities but has been moving rapidly into deep knowledge base activities. Driven by cost efficiencies, many companies have been gaining more experience in offshoring but at the same time encountering coordination and governance problems (Sidhu and Volberda, 2011), often exacerbated by the lack of a clear corporate strategy. The consequence has been what

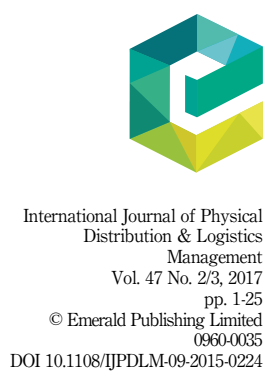


IJPDLM

$47,2 / 3$ we call an efficiency trap as companies motivated by the search for efficiencies get trapped into increasingly complex situations and therefore significant inefficiencies arise.

From this perspective, mention should be made of the costs of managing and coordinating interdependent activities in different time, language, and cultural zones (Sidhu and Volberda, 2011), referred to as "hidden" or "invisible" costs (Andersson and Pedersen, 2010; Larsen et al., 2013; Manning et al., 2011; Paz-Aparicio and Ricart, 2013). A firm would contemplate offshore outsourcing when the perceived advantages of the disintegration of value chain activities and externalization are high or superior and when the cost of resources in offshore locations are lower (Andersson and Pedersen, 2010; Kedia and Mukherjee, 2009). The costs and benefits of offshoring (and thus its value creation) depend on the activity being offshored (Kedia and Mukherjee, 2009). The nature of the activities will therefore influence the decision-making process of the managers at the disintegration stage (Kedia and Mukherjee, 2009). At a broad level, research on the general drivers of offshoring has generated much interest (King and Forkzadeh, 2008). Nevertheless, several scholars have called for further research on the offshoring of services (Caniato et al., 2015). To date, the number of studies offering empirical analysis of this has been limited (Bunyaratavej et al., 2011).

We believe, and our literature review confirms, that the HR function is special with regard to several relevant dimensions. It is more strategic and has more of an interdependent relationship with relevant corporate decisions. Furthermore, the nature of the function itself has been evolving in the past few decades.

On the one hand, the outsourcing decisions of this function had been studied mostly from a contractual (transaction cost) and a resource perspective but such decisions have not yet been integrated with this function's geographic location. On the other hand, the offshoring of service activities has been increasing and it is a prevalent phenomenon, pushed by developments in information technology and globalization trends, that has attracted the attention of scholars and practitioners. One of the areas attracting the interest of scholars focusses on how offshoring can be used as a strategy to create value (Kedia and Lahiri, 2007; Kedia et al., 2005; Lewin and Peeters, 2006; Mukherjee et al., 2013). Such value creation is analysed in terms of benefits (Bunyaratavej et al., 2008; Dunning, 1993, 1998) and costs (Kedia and Mukherjee, 2009), referred to as challenges by some authors (Manning, 2014).

In addition, pioneers in this area of offshoring have been experimenting with different governance forms from captive offshoring to outsourcing offshoring with different levels of success. DuPont is an interesting example. The company decided to offshore most of its administrative activities in Spain. However, the company follows a different strategy depending on the activity being offshored. Specifically, this strategy differs when considering HR activities. Furthermore, organizational learning in offshored companies is also affected by the experience of service suppliers and its own evolution. Service providers have been adapting what they provide and their global footprints to serve their clients better and to help them overcome the complexities associated with externalization and location decisions regarding increasingly complex activities and processes.

As we focus on a very special function with tremendous strategic implications, the HR function, all these processes and the corresponding organizational learning of the companies involved have consequences for our understanding of these decisions, externalization and location, for this particular function. In this study, we try to understand the behaviour of companies offshoring HR activities. We do this by analysing all the processes that interfere with the decision to offshore the HR function and by proposing a coevolutionary model that will help us understand the phenomenon.

The paper is organized as follows. First, we develop some of the basic theories used to understand both outsourcing and offshoring decisions. Second, we study how the offshoring of service activities has evolved from the perspective of both the client and the service providers. Next, we move into the specifics of the HR function and study the evolution of the 
function and the established models to understand its externalization. Finally, to understand offshoring (and outsourcing) of the HR function we integrate these processes into a coevolutionary model. While, conceptually, the analysis is mostly based on established literature, we ground our arguments in offshoring data from the Offshoring Research Network (ORN), an international research initiative launched at Duke University's Center for International Business and Research (CIBER), which involves partner universities in Europe and Asia. We close the paper with conclusions and implications.

Offshore human

resource activities

\section{Theory}

\section{Outsourcing and offshoring administrative activities}

The terms "outsourcing" and "offshoring" are often confused. "Offshoring" refers to the process of sourcing and coordinating functions across national borders, whereas "outsourcing" denotes the delivery of products or services by an external provider (Lewin et al., 2011). For example, those business activities performed at a subsidiary in another country, such as the HR department in a foreign subsidiary that supports local operations (i.e. local sales and distribution), are not considered offshoring. We can apply the term "offshoring" if HR services are provided offshore in support of global or home-based HR functions (Lewin, Massini and Peeters, 2009). Choosing a suitable mode is critical in terms of customer satisfaction and a firm's competitiveness (Luo et al., 2013). Figure 1 illustrates the different alternatives companies have when deciding to outsource and/or offshore their business functions.

In this paper, and based on the literature (Hutzschenreuter et al., 2011; Lewin et al., 2011; Manning et al., 2011), the following administrative activities are considered: HR, call centres, finance and accounting (F\&A), marketing and sales, and legal services. These activities are frequently deemed similar while forming a separate group. The decision to outsource these kinds of activities has been discussed frequently. Some of the first theories about reasons for outsourcing were those based on "make" or "buy" decisions.

Transaction cost economics theory (Williamson, 1993) can help to explain the increasing popularity of the outsourcing phenomenon by shedding light on how asset specificity, strategic importance, transaction frequency and contract length affect transaction costs, and when it makes sense to produce a good or service in-house or to subcontract it (Williamson, 1975). The focus, therefore, is primarily on costs and efficiency rather than revenue (Coase, 1937; Tate et al., 2009; Ceci and Prencipe, 2013). The basic benefit of offshoring - namely, cost advantages due to more economical talent and facilities - is also cited as a key reason for implementing offshore outsourcing decisions (Trent et at., 2011). Nevertheless, the consideration of hidden costs is important (Stringfellow et al., 2008; Larsen et al., 2013; Elia et al., 2015).

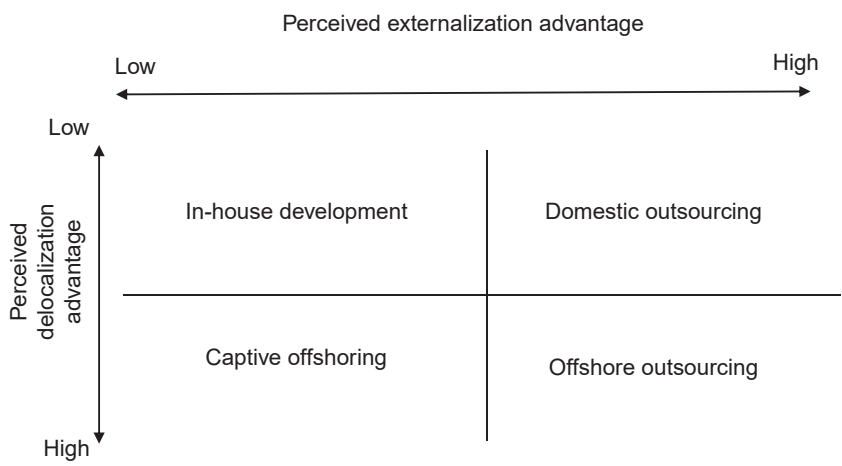

Source: Paz-Aparicio and Ricart (2013)

Figure 1.

Different sourcing models 
IJPDLM $47,2 / 3$

From a different perspective, the resourced-based view of the firm (Barney, 1991; Lepak and Snell, 1998; Prahalad and Hamel, 1990; Gilley et al., 2004) states that the capabilities of a company are dependent on the resources within it, whereby outsourcing certain resources might limit any capabilities that depend on them. This theory states that competitive advantage is not a function simply of opportunities in the external environment but also a function of what resources the firm can identify, develop, deploy, and protect (Barney, 1991; Penrose, 1959; Jahns et al., 2006). Within a context of increasing global competitive pressure, companies are advised to concentrate on their core competencies and use outsourcing to capitalize on the expertise of others (Bomberger, 1998; Porter, 1990; Prahalad and Hamel, 1990). From this perspective, offshoring is caused by the availability of, for example, qualified personnel or capabilities for redesigning the business process in offshore locations (Lewin and Peeters, 2006).

Another theory mostly applicable to offshoring is the market-based view (Jahns et al., 2006; Davidsson, 1989; Schumpeter, 1934). The main argument here is that the potential offshore locations might also become important customer markets in the future.

In addition to the reasons for outsourcing, researchers have been interested in the question of what to outsource (Harland et al., 2005). Although this question can be approached from the perspective of transaction costs, it was the introduction of the notion of core competencies that fuelled the discussion and led researchers and practitioners alike to rethink which activities could be outsourced. The question of what to outsource remains key (Hätönen and Eriksson, 2009). The challenge managers' facing is to ensure that the valuecreating potential of the activity transferred is at least maintained, if not enhanced. Research suggests that achieving this goal depends on the nature of the activity, and the degree to which knowledge is codified and embedded in an activity or location (knowledge stickiness) constitutes a barrier to effective mobility (Lampel and Bhalla, 2011).

Another theory distinguishes between core and non-core activities (Contractor et al., 2010). Quinn (1999) defines three types of activities (see Figure 2): core activities, which are those that the firm performs better than any other company (best-in-class capability); essential activities, which are those that are required to sustain its profitable operations; and non-core activities, which are those that can be outsourced easily (Contractor et al., 2010).

A finer distinction between core activities and essential activities is in line with the finer slicing of value chain activities. With this classification, a company will be able to take

Figure 2.

A finer distinction between core and non-core activities

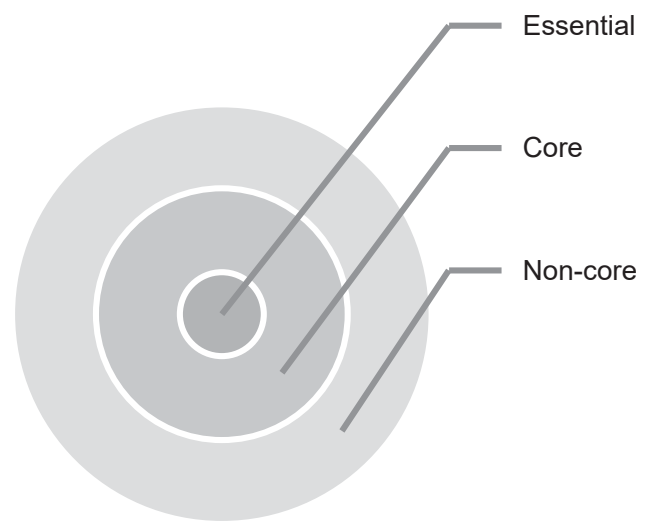

Source: Contractor et al. (2010, adapted from Quinn, 1999) 
advantage of specialization, and leaner organization increases the firm's flexibility in responding to changes in the external environment (Contractor et al., 2010).

The offshoring of administrative activities and technical services is a common business practice (Manning et al., 2011). Administrative activities refer to back-office operations that have often been viewed as peripheral to core competencies (Lewin et al., 2011). In contrast, knowledgeintensive activities involve symbolic-analytic work, being typically more complex and requiring more highly skilled personnel than administrative business services, e.g., payroll processing and call centres (Manning et al., 2010). Some authors divide the support functions into three groups: knowledge-intensive functions, such as R\&D, product development and design; idiosyncratic functions, including F\&A, HR and procurement; and quasi-autonomous functions, such as IT and call centres. Knowledge-intensive functions are characterized by open-ended, less strictly defined processes. Functions might be of strategic importance, represent core capabilities, and even involve confidential information, often making firms reluctant to externalize them (Hutzschenreuter et al., 2011). Idiosyncratic functions are particularly firm-specific and require detailed knowledge about existing processes and structures. An external governance mode may not be ideally suited (Hutzschenreuter et al., 2011).

As mentioned earlier, when considering the offshoring of a function, the possible hidden costs must be considered. These stem mainly from the unique characteristics of services. Some services have a high portion of intangible components, which are hard to express, making the specification difficult. The question is, therefore, how to offshore a service that has intangible parts and is hard to express. It is also necessary to analyse the degree to which the customer is part of the service process. In manufacturing processes, the customer does not need to be present. However, some services require customer involvement. How to facilitate this customer involvement in real time and across distances is an immediate implication for offshoring. What is more, service quality is an issue for companies (Stringfellow et al., 2008). So when service offerings are complex and loosely defined, service processes cannot be standardized, as they require complex judgments involving implicit knowledge, and steps in the process are reciprocal, so offshoring this type of service is much more challenging (Stringfellow et al., 2008). Accordingly, most companies start by offshoring simpler tasks and achieving major savings. However, as they become more involved in offshoring, the complexity increases and the savings decrease. Research findings suggest that the reason there is complexity and the limit to it can be found in the need to change the business model (Paz-Aparicio and Ricart, 2013) and the need to learn and become familiar with new ways of managing offshoring activities.

To sum up, in addition to paying attention to the function itself, companies need to think about the reasons or drivers behind offshoring, as we elaborate later on. While reducing labour costs is still the most significant factor driving offshoring decisions, a remarkable number of companies have noted that improving efficiency is more urgent (Lewin, Massini, Perm-Ajchariyawong, Sappenfield and Walker, 2009). This implies that service providers should not count on price alone as a differentiator. Companies demand consistently highquality services (Lewin, Massini, Perm-Ajchariyawong, Sappenfield and Walker, 2009). Nevertheless, firms still offshore certain activities for the sole purpose of cutting operational costs (Trent et al., 2015), although the current literature puts much greater emphasis on the search for resources and skills or on gaining operational flexibility (Hätönen and Eriksson, 2009). Firms not only seek to cut costs but also seek to create value through offshoring (Manning et al., 2011), which the following sections will examine in more detail.

\section{How has the offshoring phenomenon evolved?}

Results from the 2009 ORN Corporate Client Survey suggest there has been a shift away from captive operations in both manufacturing and high-tech and telecommunication companies. In both industries, there has been something of a shift towards local providers 
IJPDLM

$47,2 / 3$

(Lewin et al., 2011). One possible explanation for this phenomenon is the higher operational risks and costs associated with captive offshoring as providers are able to offer significant benefits of scale, as well as the opportunity to "share best practices" (Lewin et al., 2011). At the same time, companies with high transaction volumes can achieve economies of scale more easily and shorten the payback period on their captive investment.

Nevertheless, as companies steadily expand their offshoring, they face the added challenge of efficiently managing geographically dispersed units that have complex processes and require a deep understanding of local cultures (Lewin et al., 2011). The declining preference for captive operations may also be influenced by the diminishing effects of labour arbitrage due to rising wage inflation in several destination countries. Under these conditions, a third-party provider has much greater flexibility to act to keep costs down (e.g. moving operations from India to China) (Lewin et al., 2011). Research also shows that companies' motives for engaging in offshore outsourcing change over time (Lewin and Zhong, 2013; Lewin and Couto, 2007).

While many articles, books, and reports have been published in recent years about offshoring, the complex dynamics of these trends are not well understood (Manning et al., 2008). Lewin and Volberda (2011) develop a coevolutionary offshoring decision model that stresses the interactions between an activity's characteristics and managerial intentionality, path-dependent experience and knowledge accumulation as well as institutional forces that influence the decision to offshore and explain heterogeneous offshoring outcomes. Moreover, Lahiri and Kedia (2011) argue that offshore outsourcing can be understood as the coevolution of institutional and organizational factors relating to both clients and providers that enable and drive both parties towards engaging in offshore outsourcing practices.

Taking both a multilevel and coevolutionary perspective helps achieve a better understanding of the connectedness rather than just the individual significance of each trend (Manning et al., 2008).

Evolution of offshoring decisions. The offshoring of business services is increasing in scope at a very fast pace (Albertoni and Elia, 2014). Much of the traditional literature on offshoring emphasizes its cost-saving motivations while recent discussions highlight different motivations driving firms' offshoring decisions, including access to HRs and talent, knowledge, and new technologies (Kedia and Lahiri, 2007; Lewin, Massini and Peeters, 2009). Among other authors, Posani and Kenney (2003) illustrate the change in companies' mindset from cost to quality.

Companies' motivations for offshoring have changed: from just lowering costs to accessing talent and growth opportunities and seeking knowledge and new technologies (Kedia and Lahiri, 2007; Lewin, Massini and Peeters, 2009; Nieto and Rodríguez, 2011). Some authors have even suggested that a country is more likely to be a service offshoring destination the more the average wage there increases (Bunyaratavej et al., 2007) because of the importance of attracting high-skilled workers (Bunyaratavej et al., 2011).

Research also suggests there has been a progression in offshoring, which is increasingly moving into value-added activities (Lewin and Peeters, 2006). The trend is for companies increasingly to offshore more complex and higher-value-adding activities that require access to subject-matter expertise and a growing number of highly skilled and qualified workers (Lewin and Peeters, 2006). A study (Lewin, Massini and Peeters, 2009) on the factors that lead companies to decide to offshore innovation activities shows that the emerging shortage of highly skilled science and engineering talent in the USA and, more generally, the need to access qualified personnel are important explanatory factors for offshoring innovation decisions. Moreover, unlike the drivers of many other functions, labour arbitrage is less important than other forms of cost savings. The same paper concludes with a dynamic vision of companies offshoring decisions and entering a global race for talent.

Bunyaratavej et al. (2011) propose that, as offshoring activity expands in scale and scope, it will make a greater contribution to more flexible and adaptable organizational structures, and 
this will support the development of dynamic capabilities that draw from this offshoring expertise. Some companies are affected by the efficiency trap, unable to escape from the increasing complexity associated with offshoring and failing to achieve the expected efficiency gains (Lewin, Massini, Perm-Ajchariyawong, Sappenfield and Walker, 2009, Lewin et al., 2011). Several studies show that cost savings as a driver of offshoring tend to decline in importance as companies gain experience in offshoring and experiment with the offshoring of increasingly complex and advanced activities (Lewin, Massini and Peeters, 2009).

Conventional management theories such as transaction cost economics and the resourcebased view have often been challenged for downplaying the important role of organizational learning and experience (Bunyaratavej et al., 2011). Organizational learning at multiple levels of analysis (the industry, firm and managerial levels) constitutes an important area for further research into offshoring (Bunyaratavej et al., 2011). Environmental factors, managerial strategic objectives, and a firm's past experience are determinants of a firm's decisions to offshore product development functions (Lewin, Massini and Peeters, 2009; Lewin, Massini, Perm-Ajchariyawong, Sappenfield and Walker, 2009).

Additionally, existing research shows that offshoring decisions are made in a different context in the case of experienced companies. As companies gain expertise in offshoring, they start incorporating these decisions into their business and corporate strategies, rather than making isolated decisions (Massini et al., 2010). According to the latest findings of the ORN survey, more and more companies are formulating and disseminating corporate-wide strategies for guiding outsourcing and offshoring decisions at the business unit and function level and are integrating offshoring decisions into the entire corporate strategy (Manning et al., 2008; Massini et al., 2010).

Larsen et al. (2013) also show in their study that experience and a strong orientation towards organizational design in the offshoring strategy reduce the cost-estimation errors that derive from complexity. Experienced firms are expected to learn from previous offshoring initiatives and be better positioned to consider both functional and architectural modularity when making offshoring decisions (Elia et al., 2015). Firms at this stage will be better able to predict and estimate reintegration costs and the hidden costs associated with offshoring and, in particular, outsourcing, thus including the extent of architectural modularity and its consequences in the decision-making process concerning the choice of entry mode (Elia et al., 2015).

Regarding how the selection of the most appropriate governance mode has evolved, there is evidence that value-added and knowledge-based activities such as R\&D, engineering, and product design are offshored more and more and that firms prefer captive rather than outsourcing governance modes when these business functions are involved, due to the tacit and complex knowledge associated with these functions (Albertoni and Elia, 2014). The captive governance mode seems to perform better than outsourcing in terms of achieving both savings and high-quality standards (Albertoni and Elia, 2014).

Evolution of service providers. The evolution of service providers is a relevant issue that requires further investigation (Pisani and Ricart, 2016). Providers, initially focussed on serving global clients from low-cost countries, have been investing in locations closer to their clients to cover both nearshore and offshore services. Thus, service providers are evolving towards a model with the front end close to customers and their back end in low-cost countries.

Over time, with the growing availability of competent external service providers (as they also gain experience), firms may be attracted more and more by the possibility that offshore outsourcing offers in terms of reliance on external capabilities (Ellram et al., 2008; Manning et al., 2011), unless they have already accumulated significant experience with offshoring (Gooris and Peeters, 2014).

Overall, there is support for concluding that economic growth, combined with increasing experience with a sophisticated and demanding clientele, provides offshoring companies with 
IJPDLM $47,2 / 3$ more new opportunities to move up the value chain into higher-end roles (Youngdahl $e t$ al., 2010). Youngdahl et al. (2010) argue that offshore service and knowledge centres evolve to higher levels over time as a function of both economic development and changes in culture.

Another phenomenon that affects service providers is what is called reshoring. There seems to be a trend among US multinationals towards reshoring to the USA (Tate et al., 2014). But studies of this phenomenon have focussed on manufacturing activities (Tate, 2014; Tate et al., 2014; Fratocchi et al., 2014). The purpose of the research conducted by Tate et al. (2014) is to understand some of the trends that affect whether US-based companies take their production back to the USA or relocate it to different geographical locations. The manufacturing term "reshoring" is meant to indicate a generic change of location with respect to a previous offshore destination country (Fratocchi et al., 2014). It seems that, historically, organizations have looked at their manufacturing locations in too static a manner (Tate et al., 2014).

The question raised in the literature is: what is the right shoring decision? The reshoring trend started in around 2005 and has been picking up speed and becoming better known. More specifically, the concepts of backshoring (Kinkel, 2014), nearshoring (Hahn et al., 2011), and farshoring (Roza et al., 2011) have been studied as potential trends in the literature about offshoring. Although little is known so far about the magnitude of the back-reshoring phenomenon (companies' decision to reverse previous offshoring by bringing manufacturing back home), interest in this strategy has gained momentum in recent years (Fratocchi et al., 2014; Kinkel, 2014). Some multinationals are deciding to reshore the HR function, as in the case of DuPont, as will be explained. Later on we analyse the offshoring phenomenon for the HR function, which seems to be very idiosyncratic and unlike other administrative activities.

\section{Outsourcing and offshoring the HR function}

The offshoring of HR activities is an approach whereby HR functions can deliver an enhanced quality of service with reduced operating costs (Pereira and Anderson, 2012). This is a small but significant part of the market in business process offshoring (Pereira and Anderson, 2012). The offshore outsourcing of business functions is widely practised by firms in advanced economies (Lahiri and Kedia, 2011). Yet no governance mode is feasible for all support functions. Specifically, we focus on HR and the tasks usually being offshored (benefits administration, workforce deployment, HR helpdesks, payroll processing, recruitment, and staffing support, among others). An important reason behind our decision to build a model to understand the offshoring of $\mathrm{HR}$ activities is related to the evolution of the HR function over the past three decades.

At a broad level, research on general drivers of offshoring has generated much interest. However, it is increasingly being recognized that different types of services are likely to have different types of drivers (Bunyaratavej et al., 2011; Ørberg Jensen et al., 2013). Although empirical studies of business process offshoring and call centre organizations have been undertaken, the HR offshoring niche is less researched (Pereira and Anderson, 2012). Its service offerings are more complex than the business process offshoring sector generally and also the environment in which it operates is dynamic (Pereira and Anderson, 2012).

It is true that there are studies which have analysed the offshoring of administrative activities (Hutzschenreuter et al., 2011; Lewin et al., 2011; Manning et al., 2011). However, considering the large amount of literature on the function's strategic nature (Wright and McMahan, 1992; Caligiuri and Stroh, 1995; Stroh and Caligiuri, 1998; Ulrich, 1998; Baron and Kreps, 1999; Lepak and Gowan, 2010), HR activities should not be considered simply as administrative activities. Furthermore, even focussing on the more administrative HR activities (e.g. benefits administration, workforce deployment, HR helpdesks, payroll processing, recruitment, and staffing support), the authors of this study do not know 
the extent to which the drivers involved in offshoring those HR activities are the same as for other administrative activities, such as F\&A, call centres, marketing and sales, and legal services. We will try to understand this phenomenon by analysing the potential differences between offshoring HR activities and offshoring other administrative activities.

DuPont is an interesting example on which our discussion is focussed. This science company was founded in 1802 and, as of 2016, it operates in more than 90 countries. It has been offshoring some of its administrative activities for years (F\&A, HR, legal services, and so on). The company follows different strategies depending on the activities being offshored, which we will analyse in more detail.

In 1997, the company decided to offshore all its European finance functions to Asturias, in Spain, creating its own captive centre. DuPont made that decision not only to reduce labour costs but to increase efficiency by standardizing all processes. Of all the many possible locations, the company chose Spain, and specifically Asturias, due to the more attractive government subsidies and the higher skill levels of the personnel being offshored. The company started by offshoring the accounts receivable tasks and continued with other activities such as accounts payable, transfer pricing, cost accounting, general ledger accounting, permanent investment accounting, treasury, and VAT (taxes). It started to transfer activities from the USA in 2003 (permanent investment accounting and treasury). In 2006, the company decided to transfer some of its financial activities to India.

Considering this success, the company decided to offshore its HR activities, also to Asturias, by centralizing all the functions in the same place. The company created an HR-shared service centre in 2001, wholly owned by DuPont. In 2005, after four years of the centre operating as a captive centre, the company signed an agreement with Convergys Corporation, under which the service provider would provide comprehensive HR transactional services to DuPont's 60,000 current employees and 102,000 retired employees in 70 countries worldwide, using 30 languages. DuPont expected the implementation to take two years (DuPont, 2005). The reason for outsourcing the function was to achieve greater efficiencies, better service, and lower costs. DuPont considered Convergys to be the right partner to enable the transformation of its HR transactional services by standardizing, simplifying, leveraging, and automating a number of the HR processes, as DuPont's senior vice president for HR stated at the time. All DuPont employees were transferred to Convergys. However, in April 2010, the company decided to transfer the centre back to DuPont, returning to the original captive centre it had created initially. Apparently, Convergys found that implementing the contract was much more complicated than it had anticipated, probably in terms of costs and quality of service. As can be seen in discussions about shared service structures, none of the approaches commonly adopted is recognized as universally effective. Shared services are not a panacea for all functions (Aksin and Masini, 2008). Based on this case, the following question must be asked: could relocation back to the company or a decrease in HR offshore outsourcing be a trend?

The description of the DuPont case may help show that the decision to offshore a function, and specifically the HR function, is dynamic. This means that the evolution of the factors influencing the decision must be taken into account, rather than the phenomenon being seen from a static perspective.

Evolution of HR: from tactical to strategic (the "new" HR). It was not until 2001 that companies began to pay more attention to the organization and performance of their HR functions. This initiative, referred to as strategic human resource management (strategic HRM), had two goals: to contain costs and deliver maximum value to a company's business unit by realigning HR leaders as strategic partners of business leaders (Groysberg et al., 2006). Previously, the evolution of the HR function was characterized by three main stages (Groysberg et al., 2006). First, there was the tactical stage (prior to the Second World War), when the function was considered to be strictly administrative. Second, authors identified the first wave of strategic HRM, around the 1980s. At this stage, as companies grew 
IJPDLM

$47,2 / 3$

10

concerned about cost-cutting, they started attaching importance to knowledge, innovation, and human capital. HR practitioners focussed increasingly on finding the right people, developing and retaining high-potential talent, and striving for diversity. Firms started to see learning as a key deliverable to support these goals. Finally, there was the second wave of strategic HRM or "new HR" (1990s). HR was now seen as a strategic partner. This era introduced the concept of a central role for HR in implementing a firm's strategy. The HR role changed from "protector and screener to planner and change agent" (Groysberg et al., 2006). Strategic HR called for strategic deliverables: HR actions and outcomes that help execute the firm's strategy, demonstrate alignment with that strategy, motivate employees to behave strategically, and directly help implement the firm's strategy.

There is agreement in the literature that HR departments today are charged with simultaneously being strategic, flexible, efficient, and customer-oriented (Lepak and Snell, 1998). There is no question then that HR is a function that adds value to a company.

A model for understanding the decision to outsource HR. Practitioners face the challenge of deciding which $\mathrm{HR}$ activities to offshore and/or outsource. Over time, companies tend to increase the number of processes offshored. However, they are careful not to offshore their "family jewels" (Lewin and Peeters, 2006). Many services are what Reich (1991) has called "in-person services" and, as such, they are not offshorable (Dossani and Kenney, 2007), while others cannot be offshored because of the lack of offshore expertise (including managerial and risk-taking skills), legal and social obstacles, or the importance of onsite teamwork (Dossani and Kenney, 2007). Similar issues affect outsourcing but the offshoring decision has been treated more extensively. When talking specifically about the HR function, operating costs cannot be the only criterion for sourcing decisions - nor can the traditional advice to retain internally those functions associated with the company's core competency and outsource the rest. Risk management issues have to be considered as well. Issues of reliability and responsiveness, specifically with HR sourcing, may cripple the HR function (Cappelli, 2011). Transactional work in HR has to be flawless before there can be any focus on more strategic issues.

Managers need to consider more than just the core/non-core dichotomy when deciding whether an HR activity is a potential candidate for outsourcing (Conklin, 2005). Lepak and Snell (1998) extend the core/non-core focus to include uniqueness. This is the most popular model relating to the outsourcing of HR activities. These activities may range from those that are directly instrumental in achieving organizational objectives (high value) to those that are primarily administrative or transactional in nature (low value). Furthermore, HR activities may be routine (low uniqueness) or extremely idiosyncratic (high uniqueness). These scholars (Lepak and Snell) consider that HR activities with both high strategic value and high relationship features should be kept in-house, also arguing that the value (how important the task is for achieving organizational objectives) and uniqueness (non-routine activities) of HR activities differ among firms. All, too often, outsourcing decisions in HR are driven by cost considerations without an eye on broader strategic issues. An important challenge for managers is to determine which HR activities are more or less important from a strategic point of view and to choose the most appropriate structural alternative to deploy them.

Klaas et al. (1999) introduced a classification of HR activities involving four categories in order to analyse the appropriateness of outsourcing (Conklin, 2005; Shih and Chiang, 2011): generalist activities (e.g. performance appraisal), transactional activities (e.g. payroll), human capital activities (e.g. training), and recruitment and selection. They conclude that distinctive or idiosyncratic practices requiring tacit knowledge may suffer if outsourced. Classifying an activity as non-core may lead to an oversimplification of the complexity of the real business situation (Conklin, 2005). For outsourcing to be used effectively, it is essential to know which activities can and cannot be outsourced. For example, the oil and gas company BP decided to retain everything that required judgment and policy (Belcourt, 2006). 
We use the model of Baron and Kreps (1999) to assess the appropriateness of outsourcing and adapt it later to assess the appropriateness of offshoring, adding a dynamic and evolutive perspective. The model has two dimensions (see Figure 3): strategic importance (proximity to the business's core function) and interdependence (task and social).

This original model states that tasks of strategic importance and those that depend heavily on others in the firm should not be outsourced. Tasks that fall outside a business's main function and that a worker can perform to a large extent independently are more suited to outsourcing. In mixed cases, companies need to be cautious about outsourcing the function. We therefore suggest that companies offshore the function rather than outsource it. This means they will be able to keep control over it and, at the same time, take advantage of the benefits of delocalizing the activity. Offshoring is not being considered in this model, and we argue it should be included. This is why, based on the facts previously described and on the evolution of the function, we propose that a new model should be created, focussed specifically on HR offshoring.

In addition, most current offshoring research investigates the drivers in the initial stage of offshoring. However, the service offshoring industry has been progressing rapidly (Bunyaratavej et al., 2011). Companies and service providers have gained experience over time. How these trends have coevolved in recent years is discussed in detail next and should be taken into account.

We have enough indications that the function has idiosyncratic characteristics. We use ORN data to check whether the idiosyncrasies are affecting offshoring decisions by analysing the drivers, as reported by the companies, in comparison with other administrative activities.

What is different about offshoring the HR function? An exploratory analysis. This study aims to explore the offshoring of $\mathrm{HR}$ activities in order to give guidance on how to understand this phenomenon and reflect it in a coevolutionary model. It is interesting to compare the HR function with other administrative activities in terms of drivers.

This section contends that the HR function has different characteristics compared with other administrative activities and deserves special treatment due to the information managed, with the employee being the service's end customer. When talking specifically about the HR function, operating costs cannot be the only criterion for sourcing decisions. This section also argues that the reason for offshoring HR activities goes way beyond cost reduction and that companies follow such a strategy as a tool for creating business opportunities.

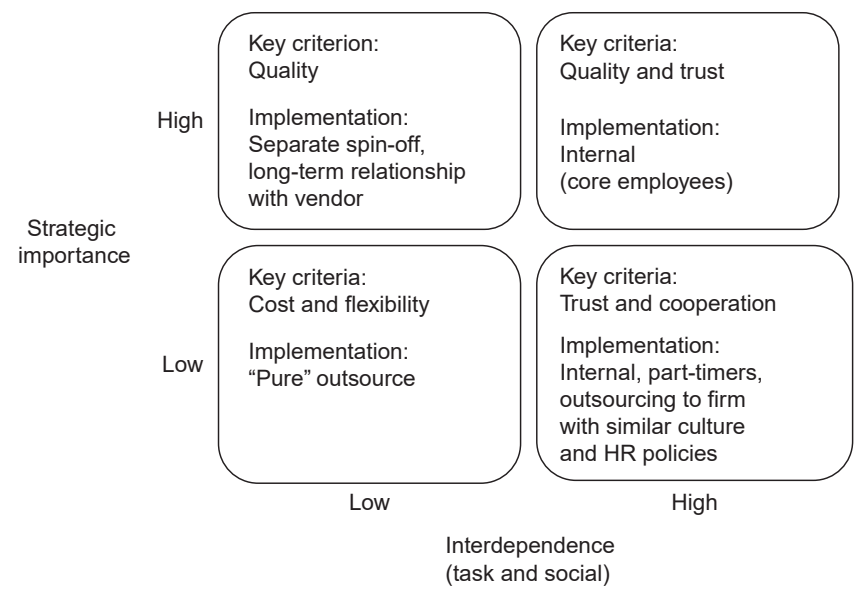

Source: Groysberg et al. (2006, adapted from Baron and Kreps, 1999)

Figure 3. A diagnostic schema for assessing the appropriateness of outsourcing
Offshore human resource activities 
IJPDLM

$47,2 / 3$

The aim of this exploratory analysis is twofold. First, it is intended to group the main drivers into several dimensions for offshoring administrative activities. Second, we will investigate the potential difference between these drivers when companies offshore the HR function or other administrative activities.

$O R N$. The ORN is an international research initiative launched at Duke University's CIBER that involves partner universities in Europe and Asia. Since 2004, it has studied major offshoring drivers, risks, location choices, delivery model choices, performance indicators, and future plans, based on annual client and service provider surveys. The ORN database includes 1,990 US and European client firms and more than 700 service providers. The overall objective of the ORN is to track, both annually and over several years, the offshoring of administrative and technical functions, from pioneering early adopters to majority adopters (Lewin and Peeters, 2006). The survey helps the ORN to create the first firm-level database with information on when each company started offshoring a particular business function, where it was offshored, the service delivery model used and why. Survey items are answered with regard to every offshore implementation - that is, every function offshored in one particular location - and not with regard to the company as a whole. This provides much more precise insight.

Sample data and measures. For this section, an empirical analysis was conducted that relies on data from the ORN survey. The data used related to ORN corporate client surveys conducted in the USA and Europe from 2005 to 2011, which constitute all the existing data from the ORN. The sample consists of 1,874 activities that were being offshored or were being considered for offshoring. Out of all the companies offshoring administrative activities, 14.2 per cent said they were offshoring or considering offshoring HR activities, 27.8 per cent F\&A, 39 per cent call centres, 14.2 per cent marketing and sales, and 4.7 per cent legal services.

Methods of analysis. The SPSS statistical software was used to run the analysis. In all, 16 different offshoring drivers used in the ORN survey (see Table I) were analysed using a five-point Likert scale. An exploratory factor analysis (EFA) was carried out - this is a statistical method used to derive main categories from different drivers of offshoring (eigenvalues higher than 1). In total, 16 drivers were introduced. The matrix of correlations shows that all variables are significantly correlated. The Kaiser-Meyer-Olkin (KMO) and Bartlett's tests show the appropriateness of conducting a factor analysis (The KMO value is 0.807, close to 1 , and the Bartlett's sphericity test is significant.). Commonalities for each variable, which determine how much of each variable is included in each factor, are good for the analysis. The five factors obtained explain 62.6 per cent of the variance from the 16 drivers included in the analysis. We used an exploratory instead of a confirmatory factor analysis (CFA) due to the lack of literature on the drivers of HR offshoring.

The analysis supports the existence of five categories of offshoring drivers, which can be described and named as shown in Table I.

A regression model was used to investigate whether there were differences regarding drivers between the different functions. Specifically, we used a binary logistic regression model that estimates the probability of offshoring the $\mathrm{HR}$ function (dependent variable $=1$ ) compared with its alternative - offshoring other administrative activities (dependent variable $=0$ ), conditional on the driver variables (the five factors arising from the EFA).

Dependent variable. The different administrative activity functions being offshored were included in the database. As we wanted to analyse the drivers that might be differentiating factors in the decision to offshore the HR function or to offshore other administrative activities, a binary variable was created. This variable takes the value 1 when the $\mathrm{HR}$ activity is being offshored or is being considered for offshoring and takes the value 0 if the activity that is being offshored or is being considered for offshoring is another administrative activity ( $\mathrm{F} \& \mathrm{~A}$, call centres, or marketing and sales). 


\begin{tabular}{|c|c|c|c|c|c|c|c|}
\hline & & & Descr & iptive statistic & & & Jttshore \\
\hline & Mean & SD & Factor & Eigenvalues & $\begin{array}{c}\text { Cumulative } \\
\text { variances }\end{array}$ & $\begin{array}{c}\text { Cronbach's } \\
\alpha\end{array}$ & $\begin{array}{l}\text { numan } \\
\text { resource }\end{array}$ \\
\hline Driver_Increasing speed to market & 2.92 & 1.402 & Strategic drivers & 4.551 & 28.442 & 0.831 & activities \\
\hline $\begin{array}{l}\text { Driver_Access to new markets for } \\
\text { products and services }\end{array}$ & 2.54 & 1.385 & & & & & \\
\hline Driver_Part of a global strategy & 3.54 & 1.398 & & & & & 13 \\
\hline Driver_Differentiation strategy & 2.66 & 1.301 & & & & & \\
\hline Driver_Growth strategy & 3.61 & 1.174 & & & & & \\
\hline $\begin{array}{l}\text { Driver_Domestic shortage of } \\
\text { qualified personnel }\end{array}$ & 2.54 & 1.292 & & & & & \\
\hline $\begin{array}{l}\text { Driver_Exploit location-specific } \\
\text { advantages }\end{array}$ & 3.13 & 1.375 & Location drivers & 1.981 & 40.822 & 0.848 & \\
\hline $\begin{array}{l}\text { Driver_Exploit country-specific } \\
\text { advantages }\end{array}$ & 3.03 & 1.444 & & & & & \\
\hline $\begin{array}{l}\text { Driver_Enhancing efficiency } \\
\text { through business process redesign }\end{array}$ & 3.48 & 1.269 & $\begin{array}{l}\text { Efficiency and } \\
\text { resource drivers }\end{array}$ & 1.310 & 49.007 & 0.648 & \\
\hline $\begin{array}{l}\text { Driver_Need to improve service } \\
\text { levels }\end{array}$ & 3.39 & 1.195 & & & & & \\
\hline $\begin{array}{l}\text { Driver_Enhancing system } \\
\text { redundancy } \\
\text { Driver_Access to qualified }\end{array}$ & 2.61 & 1.296 & & & & & \\
\hline $\begin{array}{l}\text { Driver_Access to qualified } \\
\text { personnel offshore }\end{array}$ & 3.52 & 1.175 & & & & & \\
\hline $\begin{array}{l}\text { Driver_Competitive pressure } \\
\text { (e.g. competitors' margin) }\end{array}$ & 3.34 & 1.233 & Industry drivers & 1.132 & 56.084 & 0.664 & $\begin{array}{r}\text { Table I. } \\
\text { Descriptive statistics }\end{array}$ \\
\hline Driver_Accepted industry practice & 2.93 & 1.165 & & & & & and factor analysis \\
\hline Driver_Other cost savings & 3.73 & 1.170 & Cost drivers & 1.043 & 62.603 & 0.683 & the 16 drivers us \\
\hline Driver_Labour cost savings & 4.26 & 0.996 & & & & & \\
\hline
\end{tabular}

Independent variables. Because this analysis tries to find differences between the drivers when offshoring HR or any other administrative activity, the independent variables will be the five factors that explain the reasons behind the decision to offshore the different activities.

Control variables. There are certain variables that should be considered in the model. We control for the offshoring location (Lewin, Massini and Peeters, 2009; Lewin, Massini, Perm-Ajchariyawong, Sappenfield and Walker, 2009; Caniato et al., 2015), which involves the country to which a certain activity is offshored. We created dummy variables for each country.

We also considered the survey year as another control variable (Gooris and Peeters, 2014) in the regression analysis, as Gooris and Peeters considered it might influence the drivers. This basically took into account those authors' dynamic perspective of the offshoring process. We created dummy variables for each survey year.

We also control for the industry (Lewin, Massini and Peeters, 2009; Lewin, Massini, Perm-Ajchariyawong, Sappenfield and Walker, 2009). Six industry dummies are used as control variables in the regression.

With regard to governance mode, the different models were set as either outsource or captive offshoring (Manning et al., 2008; Roza et al., 2001). Firms offshore-outsource when they outsource to a domestic partner, an international party, and/or a local party, when they apply more than one of these or when they answer only "outsourcing" in the survey. Captive offshoring firms form joint ventures or keep full control of overseas activities (Anderson and Gatignon, 1986; Roza et al., 2011). The small number of responses meant that this variable had to be excluded from our model and that we could not control for the global number of employees of each company.

Reliability and validity. In order to determine the survey's statistical validity, several statistical tests were performed on the data. To evaluate the conceptual constructs in the data, 
IJPDLM

$47,2 / 3$

14

a CFA was used to assess the dimensionality and reliability of each driver. A CFA was performed on all the responses in order to validate these constructs by examining individual item reliability and internal consistency (see Table I).

Calculating Cronbach's $\alpha$ coefficients for each driver assists in the assessment of construct reliability. According to the test results, each driver has an $\alpha$ value greater than or very close to 0.7 and, therefore, these values were considered reliable (Huang et al., 2015). Boehe (2010) considers coefficients above 0.6 to be acceptable for "initial stages of basic research", which is the case for the constructs in this study.

Table II reports Pearson correlation coefficients between explanatory variables.

Results. The factor analysis shows the categorization of five sets of drivers for offshoring administrative activities (see Table I). Support was found for the three theoretical categories of drivers (referred to as cost, resource, and entrepreneurship drivers) defined by Roza et al. (2011) and for two more. This study took into account 16 drivers, compared with nine in Roza et al. (2011). It is suggested that this study helps to achieve a better understanding of the offshoring drivers. This study's findings show that offshoring might be used as a valuecreating strategy focussed on growth (Lewin and Peeters, 2006) - what this section calls strategic drivers - or it may be understood on the basis of location, resource (Roza et al., 2011) or efficiency-seeking reasons, industry and/or cost drivers (Roza et al., 2011).

The analysis of the binary logistic regression results reveals that, regarding the offshoring drivers, the results confirm there are significant differences between the drivers for HR and those for other administrative activities. Essentially, offshoring the HR function is driven, in comparison with other administrative activities, more by strategic reasons and less by resource or efficiency-seeking solutions.

Furthermore, regarding the value of the odds ratio given in the right-hand column labelled exp $(B)$ of Table III, for example, in the case of strategic factors, based on the positive relationship with the variable HR offshoring being "yes", the value of the odds ratio is 1,564. This means that the decision to offshore the HR function is driven 1,564 times more by strategic reasons than the decision to offshore other administrative activities. The efficiency driver variable shows that a negative relationship with the dependent variable (offshoring HR being "yes") has an odds ratio of 0.572, which means that, when a company makes a decision about offshoring the HR function, it is 0.572 times less likely to offshore for efficiency reasons. Accordingly, a company deciding to offshore the HR function will be influenced more by strategic reasons and less by efficiency reasons than would be the case with a decision to offshore another administrative activity.

These results are in line with the theory about HR. The more important strategic reasons for offshoring the HR function are consistent with the evolution of the function from the tactical stage to the "new HR", as explained before.

Even though we do not find any significant difference between the other drivers (location, industry, and cost), the difference we found for efficiency drivers may be understood based on previous research. It is quite common in the literature to relate outsourcing and offshoring to a

Table II.

Correlations of the explanatory variables

\begin{tabular}{lccccr}
\hline Construct & 1 & 2 & 3 & 4 & 5 \\
\hline Strategic drivers & 1 & & & & \\
Location drivers & $0.582^{*}$ & 1 & & & \\
Efficiency and resource drivers & $0.540^{*}$ & $0.460^{*}$ & 1 & & \\
Industry drivers & $0.451^{*}$ & $0.435^{*}$ & $0.455^{*}$ & 1 & \\
Cost drivers & $-0.409^{*}$ & $-0.226^{*}$ & 0.032 & $0.103^{*}$ & 1
\end{tabular}

Notes: $n=1,874$ observations. The table contains Pearson correlations between variables. *Correlation is significant at the 0.01 level (two-tailed) 


\begin{tabular}{|c|c|c|c|c|c|c|c|}
\hline & $B$ & $\mathrm{SE}$ & Wald & $\mathrm{df}$ & Sig. & $\operatorname{Exp}(B)$ & Ottshor \\
\hline Strategic drivers & 0.447 & 0.163 & 7.541 & 1 & 0.006 & 1.564 & resource \\
\hline Location drivers & -0.107 & 0.116 & 0.839 & 1 & 0.360 & 0.899 & \\
\hline Efficiency drivers & -0.559 & 0.143 & 15.342 & 1 & 0.000 & 0.572 & activ \\
\hline Industry drivers & 0.132 & 0.136 & 0.950 & 1 & 0.330 & 1.141 & \\
\hline Cost drivers & 0.174 & 0.138 & 1.585 & 1 & 0.208 & 1.190 & \\
\hline India & 0.948 & 0.202 & & & 0.000 & & 15 \\
\hline Africa & 1.212 & 0.554 & & & 0.029 & & \\
\hline Asia & 1.155 & 0.301 & & & 0.000 & & \\
\hline Australia & 0.899 & 0.565 & & & 0.111 & & \\
\hline China & 1.329 & 0.498 & & & 0.008 & & \\
\hline Eastern Europe & 0.649 & 0.291 & & & 0.025 & & \\
\hline Latin America & 0.797 & 0.263 & & & 0.002 & & \\
\hline Middle East & 0.728 & 0.591 & & & 0.218 & & \\
\hline USA & 0.828 & 0.399 & & & 0.038 & & \\
\hline Western Europe & 0.769 & 0.265 & & & 0.004 & & \\
\hline Finance and insurance & 0.266 & 0.218 & & & 0.222 & & \\
\hline Professional services & -0.153 & 0.189 & & & 0.419 & & \\
\hline Retail & 0.507 & 0.454 & & & 0.264 & & \\
\hline Software & 2.178 & 1.033 & & & 0.035 & & \\
\hline Technical services & 0.812 & 0.287 & & & 0.005 & & \\
\hline Transportation & 0.792 & 0.614 & & & 0.197 & & \\
\hline Survey year 2006 & 0.946 & 0.347 & & & 0.006 & & \\
\hline Survey year 2007 & 0.926 & 0.347 & & & 0.008 & & \\
\hline Survey year 2009 & 0.947 & 0.361 & & & 0.009 & & \\
\hline Survey year 2011 & 1.143 & 0.362 & & & 0.002 & & \\
\hline Constant & -17.730 & & & & & & \\
\hline-2 log likelihood & $1,415.536$ & & & & & & Results of the \\
\hline \multicolumn{7}{|c|}{ Note: $n=1,874$ observations } & logistic regression \\
\hline
\end{tabular}

firm's approach to managing activities. For instance, the offshoring of advanced tasks is associated with greater maturity and strategic objectives, while efficiency-seeking strategies for simple tasks aim to improve operational performance (Caniato et al., 2015). The efficiencyseeking motive is associated with the possibility of saving on wages and other operational costs and/or accessing specialist resources. At the same time, Caniato et al. (2015) suggest that firms offshore advanced tasks not in order to save costs but for the purpose of making a broader and deeper use of their global knowledge network. Judging from the data analysed in this study, HR offshoring seems to be driven by different reasons than is the case with other administrative activities and it seems to be more strategic and less efficiency-focussed. This lends support to the idea of designing a model to understand the offshoring of the HR function independently from other administrative activities.

\section{A coevolutionary model of HR offshoring}

Q5 Based on the theory of the offshoring phenomenon and supported by, on the one hand, the results from the ORN data (described in 2.3.3) - which seem to show differences between the strategic and efficiency drivers when considering whether to offshore HR or other administrative activities - and, on the other hand, the dynamism reflected in the DuPont case, we develop a model for understanding the HR offshoring phenomenon. We adapt the model created by Baron and Kreps (1999), which was designed for understanding the appropriateness of outsourcing the HR function.

Although we understand that much of the literature focusses on the reasons for offshoring or outsourcing from a static perspective (for a review, see Lewin and Volberda, 2011), 
IJPDLM

$47,2 / 3$

we argue that companies will make the appropriate decision to offshore HR activities only if they understand the situation from a dynamic perspective (Schmeisser, 2013). It has been seen in this study that companies offshoring HR activities or considering doing so are still overly driven by cost considerations (see average values in Table I). Additionally and as expected, it is found that they are driven by strategic drivers and significantly more so than is the case with other administrative activities (see Table III). Although it is known that companies continue to base their decision of location choice on cost, we have also found that the suggested evolution of the HR function is being taken into account, in a move towards more strategic and service quality-related factors. This may help explain the trend of some multinationals to return to captive centres after offshore outsourcing (DuPont, 2005).

We contend that companies should address their decision to offshore HR activities from a dynamic perspective. Companies need to be aware of the following three processes, which constantly change.

First, the evolution of the HR function. As posited in this paper, the HR function itself has been evolving. The HR function and other parts of the firm are increasingly interdependent, and there are more and more strategic demands and a tremendous push to cut costs. Here again, the different activities within the HR function should be considered. Although the HR function has evolved globally, there may be differences in how different types of activity have evolved (benefits administration, workforce deployment, HR helpdesks, payroll processing, recruitment, staffing support, etc.).

Second, the evolution of service providers. Global providers, initially focussed on serving global clients from their location in low-cost countries, have been investing closer to their clients to cover both nearshore and offshore services. A similar trend can be observed with domestic providers in many countries that create captive centres in low-cost countries to reduce the cost of their service by leveraging offshoring. Overall, service providers are evolving towards a model with their front end close to customers and their back end in low-cost countries.

And third, the evolution of offshoring decisions. In parallel with the two processes above, there have been major changes in companies' offshoring decisions. There has been a progression in offshoring (Lewin and Peeters, 2006). Companies started with production, moved into simple administrative functions (semiautonomous activities) and later into IT and call centres and from there to R\&D and product development. Therefore, companies have been moving increasingly into higher value-added activities. At the same time, major changes are found in their motivations, which go from just a desire for low costs to access to talent and growth opportunities in those countries. Furthermore, as companies gain expertise in offshoring, they start incorporating these decisions into their business and corporate strategies, so providing an overall framework for previously isolated decisions. Of course, those changes are developed in parallel with the previously mentioned changes in service providers, creating a very different context for offshoring decisions in experienced companies. Last but not the least, some companies are affected by the efficiency trap, unable to escape from the increasing complexity associated with offshoring and failing to achieve the efficiency gains they expected (Lewin, Massini, Perm-Ajchariyawong, Sappenfield and Walker, 2009, Lewin et al., 2011), as in the case of DuPont.

By combining the three processes above, a coevolutionary perspective may be gained for understanding the changes in the HR function as it relates to offshoring decisions. This dynamic perspective is vital for making real sense of the type of changes taking place in some multinationals (such as DuPont), as well as for gaining a general understanding of the offshoring of such an important and relevant function. As illustrated in Section 2.3.3, the ORN data show that the offshoring of HR activities is driven more by strategic reasons and less by efficiency reasons than is the case with other administrative activities. This supports the idea that HR offshoring should be studied separately from the 


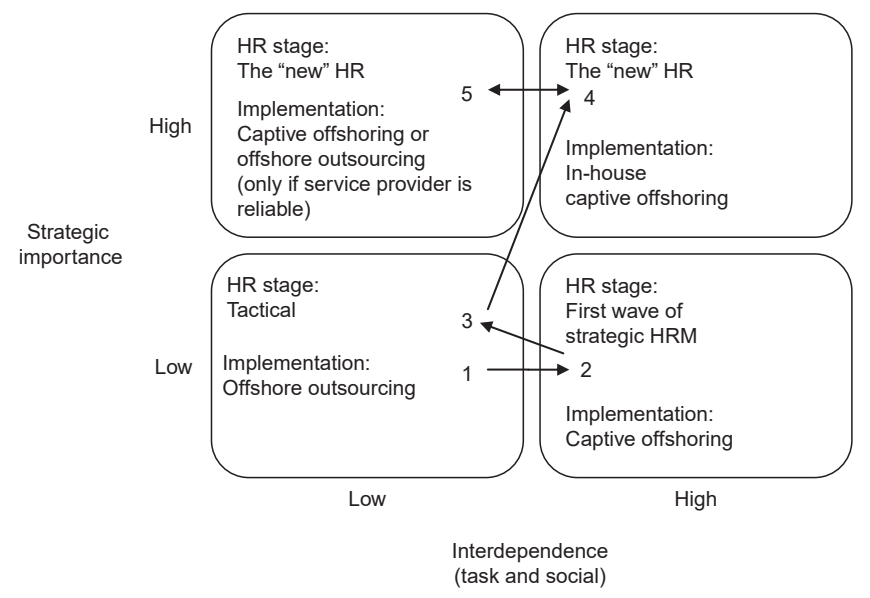

Offshore human resource activities

Source: The authors

Figure 4.

Coevolutionary model of HR activity offshoring

offshoring of other functions. Therefore, outsourcing and offshoring HR decisions are integrated into Figure 4, as a summary of our proposed model. We suggest that any company could be identified in this coevolutionary model in any of the five scenarios we describe.

Companies at the tactical stage or those considering the HR function as a purely administrative activity are willing to offshore-outsource (bottom left square). Companies in this scenario (scenario 1) seem to be driven exclusively by cost and flexibility. The company considers the function to be of low strategic importance and the interdependence with the rest of the company's functions is also considered low.

Those companies that are close to the first wave of strategic HRM will consider captive offshoring, as they are probably concerned about the interdependence of the different HR activities (bottom right square). To illustrate this situation (scenario 2), we may think about DuPont when it initially considered offshoring the function. The key criteria for companies making this decision are trust and cooperation, which helps us understand why companies at this stage decide that the best governance mode is captive offshoring.

However, from this perspective, because of the evolution of the service providers and a company's expertise in offshoring, it should be no surprise to see a drift back to the bottom left square, to offshore outsourcing (scenario 3). The case of DuPont describes this situation, when it offshore-outsourced HR activities to Convergys. Thanks to information technology, suitable changes in processes (re-engineering) and the changes in providers' services, interdependence difficulties can be resolved and rendered compatible with offshore locations.

When a company realizes that the HR function is actually strategic ("new" HR), while at the same time reaching the efficiency trap, the company moves to the top right square, where it decides the best thing to do is to internalize the function, sometimes being flexible because of the improved services offered by service providers. In this situation (scenario 4), the company is deciding to create a captive centre, taking advantage of the delocalization of the activities but not outsourcing them, as quality and trust are the key decision criteria. This is, in fact, the last scenario of the DuPont case.

Regarding the last scenario (scenario 5), when the function is considered to be of strategic importance, although the company does not see much interdependence between the different HR activities (top left square), it will consider mixed cases but will consider offshore outsourcing only if the service provider is reliable. This is the situation in which companies rely exclusively on quality in order to offshore the function. 
IJPDLM

$47,2 / 3$
In summary, several factors should be taken into account when analysing the proposed model. As previously described, any company can enter at different stages. Additionally, different activities may be treated differently within the HR function. On the one hand, the strategic importance and interdependence of benefits administration and HR helpdesks may differ among companies. On the other hand, how the activity evolves within the company should be considered. The same activity may evolve differently depending on the company. How the company can cope with the efficiency trap should also be considered. Has the company developed any corporate governance mode to cope with it? Two moderating factors have been added to our model. One is the experience a company has of outsourcing and offshoring an activity within its value chain, and the other is the experience and expertise of service providers. The anecdotal evidence in the DuPont case (DuPont, 2005) is consistent with this coevolutionary model. However, to really test the model, additional longitudinal data and cases are required. We claim that the model has to be absolutely dynamic in order to show how companies make the decision to offshore their HR activities as processes change over time.

As discussed, this coevolutionary model can be used to make sense of the case of some multinationals. As we are trying to verify whether this model could be used for other companies, it would be interesting to see what other companies have done regarding the offshoring of their HR activities. We argue that the evolution of the three processes involved in the decision to offshore HR activities (service providers, expertise in offshoring, and the HR function) is the key to understanding the behaviour of companies offshoring their HR activities. The dynamic model we have created represents this evolution and supports the decision being made by managers.

\section{Conclusions and implications}

In this paper we focus on an HR function and a company's decision to externalize, offshore or both. The HR function is peculiar because of its high level of interaction with other corporate decisions as well as because of its strategic content. It is well known that many processes of the HR function are very strategic, giving rise to the so-called strategic HRM function. Previous literature has shown that issues of quality and trust influence the ability of companies to seek external help and outsource part or all of this function.

In addition, changes in information technology have made it feasible to move increasingly complex service activities offshore. It has been shown that even R\&D and product development activities are now being offshored, following different governance structures. The main driver, but not the only one, has always been the search for better costs and efficiencies. Companies have also discovered many additional sources of talent in foreign countries.

To make things even more complex, the growth of offshoring has fuelled the development of a very global and innovative service provider industry. These service providers, aware of the difficulties faced by their clients and potential clients, have also been evolving, developing an intricate web of global structures and therefore increasing the quality of their services and the trust in them.

All these aspects associated with the evolution of the HR function, organizational learning about offshore activities, and the development of service providers should be integrated - as we have done here - into a comprehensive model for making better decisions about these complex issues of externalizing and locating HRM functions around the world. For a real understanding of these decisions, it is necessary to integrate what are essentially three processes moving in diverging directions. First, as indicated, the HR function is getting more and more strategic. Ceteris paribus, the consequence should be to keep the function captive and local. At the same time, companies gain experience in offshoring other administrative activities and eventually learn how to overcome their efficiency trap. 
In addition, service providers are also learning and getting close to companies with additional onshore resources. The consequence of these last two processes is an increase in trust and an improvement in information technology and governance capabilities, all of which leads towards greater outsourcing and offshoring in a twin search for lower costs and better talent. When the three processes are combined, different trajectories can be seen to be evolving. For instance, some companies may decide to offshore with a captive centre and move into outsourcing offshore later on or vice versa - outsource first onshore to develop the required trust and let the service provider offshore some parts of the outsourced function. As these learning processes combine with the natural evolution of the function, more complex trajectories can be seen. We claim that our model helps to achieve an understanding of such integration and drives practitioners to make better decisions. By integrating such processes, we can enrich our theoretical understanding from basic contractual and resource-dependent perspectives to a multidisciplinary model.

Even more importantly, we can help decision makers to navigate these turbulent waters and make better decisions. Those decisions should consider the costs and benefits of both outsourcing and offshoring simultaneously, taking into account the company's stage in the evolution of the HR function, the experience of governing and coordinating offshore activities, and the experience of the service providers the decision makers are considering using.

\title{
Acknowledgements
}

The authors acknowledge the Offshoring Research Network as the originator and the distributor of the data. This organization does not bear any responsibility for the authors' analysis and interpretations of the data. The authors appreciate financial support received from the Spanish Ministry of Economy and Competitiveness through Grant No. ECO2015-68343-R. The authors would also like to thank Guest-Editor Wendy L. Tate and the three anonymous reviewers for their insightful and constructive comments throughout the review process.

\author{
Glossary \\ F\&A finance and accounting \\ HR human resources \\ HRM human resource management \\ ORN Offshoring Research Network \\ R\&D research and development
}

\section{References}

Aksin, O.Z. and Masini, A. (2008), "Effective strategies for internal outsourcing and offshoring of business services: an empirical investigation”, Journal of Operations Management, Vol. 26 No. 2, pp. 239-256.

Albertoni, F. and Elia, S. (2014), "The global sourcing of business services: evidence from the offshoring research network survey", Journal of Industrial and Business Economics, Vol. 41 No. 2, pp. 131-146.

Anderson, E. and Gatignon, H. (1986), "Modes of foreign entry: a transaction cost analysis and propositions", Journal of International Business Studies, Vol. 17 No. 3, pp. 1-26.

Anderson, V. (2015), "International HRD and offshore outsourcing: a conceptual review and research agenda”, Human Resource Development Review, Vol. 14 No. 3, pp. 259-278.

Q6 Andersson, U. and Pedersen, T. (2010), "Organizational design mechanisms for the R\&D function in a world of offshoring", Scandinavian Journal of Management, Vol. 26, pp. 431-438.

Barney, J. (1991), "Firm resources and sustained competitive advantage", Journal of Management, Vol. 17 No. 1, pp. 99-120. 
IJPDLM

$47,2 / 3$

Q7

Baron, J.N. and Kreps, D.M. (1999), Strategic Human Resources: Frameworks for General Managers, John Wiley \& Sons Inc., N.

Belcourt, M. (2006), "Outsourcing: the benefits and the risks", Human Resource Management Review, Vol. 16 No. 2, pp. 269-279.

Boehe, D.M. (2010), "Captive offshoring of new product development in Brazil", Management International Review, Vol. 50 No. 6, pp. 747-773.

Bunyaratavej, K., Doh, J.P. and Hahn, E.D. (2008), "Multinational investment and host country development: location efficiencies for service offshoring", Journal of World Business, Vol. 43 No. 2, pp. 227-242.

Bunyaratavej, K., Hahn, E.D. and Doh, J.P. (2007), "International offshoring of services: a parity study", Journal of International Management, Vol. 13 No. 1, pp. 7-21.

Bunyaratavej, K., Doh, J.P., Hahn, E.D., Lewin, A.Y. and Massini, S. (2011), "Conceptual issues in services offshoring research: a multidisciplinary review", Group and Organization Management, Vol. 36 No. 1, pp. 70-102.

Caligiuri, P.M. and Stroh, L.K. (1995), "Multinational corporation management strategies and international human resources practices: bringing IHRM to the bottom line", The International Journal of Human Resources Management, Vol. 6 No. 3, pp. 494-507.

Caniato, F., Elia, S., Luzzini, D., Piscitello, L. and Ronchi, S. (2015), "Location drivers, governance model and performance in service offshoring", International Journal of Production Economics, Vol. 163, pp. 189-199.

Cappelli, P. (2011), "HR sourcing decisions and risk management”, Organizational Dynamics, Vol. 40 No. 4, pp. 310-316.

Ceci, F. and Prencipe, A. (2013), "Does distance hinder coordination? Identifying and bridging boundaries of offshored work", Journal of International Management, Vol. 19 No. 4, pp. 324-332.

Coase, R.H. (1937), "The nature of the firm”, Economica, Vol. 4 No. 16, pp. 386-405.

Conklin, D.W. (2005), "Risks and rewards in HR business process outsourcing", Long Range Planning, Vol. 38 No. 6, pp. 579-598.

Contractor, F.J., Kumar, V., Kundu, S.K. and Pedersen, T. (2010), "Reconceptualizing the firm in a world of outsourcing and offshoring: the organizational and geographical relocation of high-value company functions", Journal of Management Studies, Vol. 47 No. 8, pp. 1417-1433.

Davidsson, P. (1989), "Entrepreneurship - and after? A study of growth willingness in small firms", Journal of Business Venturing, Vol. 4 No. 3, pp. 211-226.

Demirbag, M., Mellahi, K., Sahadev, S. and Elliston, J. (2012), "Employee service abandonment in offshore operations: a case study of a US multinational in India", Journal of World Business, Vol. 47 No. 2, pp. 178-185.

Dossani, R. and Kenney, M. (2007), "The next wave of globalization: relocating service provision to India”, World Development, Vol. 35 No. 5, pp. 772-791.

Dunning, J.H. (1993), Multinational Enterprises and the Global Economy, Addison-Wesley, Reading.

Dunning, J.H. (1998), "Location and the multinational enterprise: a neglected factor?", Journal of International Business Studies, Vol. 29 No. 1, pp. 45-66.

DuPont (2005), "DuPont selects Convergys to provide transactional global human resource services", available at: www2.dupont.com/Media_Center/en_US/news_releases/2005/article20051102b. html (accessed 9 September 2013).

Elia, S., Narula, R. and Massini, S. (2015), "Disentangling the role of modularity and bandwidth in entry mode choice: the case of business services offshoring", Discussion Paper No. JHD-2015-06, The John H Dunning Centre for International Business, Henley Business School, University of Reading.

Ellram, L.M., Tate, W.L. and Billington, C. (2008), "Offshore outsourcing of professional services: a transaction cost economics perspective", Journal of Operations Management, Vol. 26 No. 2, pp. 148-163. 
Fratocchi, L., Di Mauro, C., Barbieri, P., Nassimbeni, G. and Zanoni, A. (2014), "When manufacturing moves back: concepts and questions", Journal of Purchasing and Supply Management, Vol. 20 No. 1, pp. 54-59.

Gilley, K.M., Greer, C.R. and Rasheed, A.A. (2004), "Human resource outsourcing and organizational performance in manufacturing firms", Journal of Business Research, Vol. 57 No. 3, pp. 232-240.

Offshore human

resource activities

González-Loureiro, M., Dabić, M. and Puig, F. (2014), "Global organizations and supply chain: new research avenues in the international human resource management", International Journal of Physical Distribution \& Logistics Management, Vol. 44 Nos 8/9, pp. 689-712.

Gooris, J. and Peeters, C. (2014), "Home-host country distance in offshore governance choices", Journal of International Management, Vol. 20 No. 1, pp. 73-86.

Groysberg, B., McLean, A.M. and Reavis, C. (2006), "Delivering strategic human resource management”, Harvard Business School Teaching Note No. 9-405-049, Boston, MA.

Hahn, E.D., Bunyaratavej, K. and Doh, J.P. (2011), "Impacts of risk and service type on nearshore and offshore investment location decisions: an empirical approach", Management International Review, Vol. 51 No. 3, pp. 357-380.

Harland, C., Knight, L., Lamming, R. and Walker, H. (2005), "Outsourcing: assessing the risks and benefits for organizations, sectors and nations", International Journal of Operations and Production Management, Vol. 25 No. 9, pp. 831-850.

Hätönen, J. and Eriksson, T. (2009), "30+ years of research and practice of outsourcing - exploring the past and anticipating the future", Journal of International Management, Vol. 15 No. 2, pp. 142-155.

Huang, Y.-C., Rahman, S., Wu, Y.-C.J. and Huang, C.-J. (2015), "Salient task environment, reverse logistics and performance", International Journal of Physical Distribution \& Logistics Management, Vol. 45 Nos 9/10, pp. 979-1006.

Hutzschenreuter, T., Lewin, A.Y. and Dresel, S. (2011), "Governance modes for offshoring activities: a comparison of US and German firms”, International Business Review, Vol. 20 No. 3, pp. 291-313.

Jahns, C., Hartmann, E. and Bals, L. (2006), "Offshoring: dimensions and diffusion of a new business concept", Journal of Purchasing and Supply Management, Vol. 12 No. 4, pp. 218-231.

Kedia, B.L. and Lahiri, S. (2007), "International outsourcing of services: a partnership model”, Journal of International Management, Vol. 13 No. 1, pp. 22-37.

Kedia, B.L. and Mukherjee, D. (2009), "Understanding offshoring: a research framework based on disintegration, location and externalization advantages", Journal of World Business, Vol. 44 No. 3, pp. 250-261.

Kedia, B.L., Lahiri, S. and Lovvorn, A. (2005), "Seeking competitive advantage on distant shores", European Business Forum, Vol. 21, pp. 37-40.

Kinkel, S. (2014), "Future and impact of backshoring - some conclusions from 15 years of research on German practices”, Journal of Purchasing and Supply Management, Vol. 20 No. 1, pp. 63-65.

Klaas, B.S., McClendon, J.A. and Gainey, T.W. (1999), "HR outsourcing and its impact: the role of transaction costs", Personnel Psychology, Vol. 52 No. 1, pp. 113-136.

Lahiri, S. and Kedia, B.L. (2011), "Co-evolution of institutional and organizational factors in explaining offshore outsourcing”, International Business Review, Vol. 20 No. 3, pp. 252-263.

Lampel, J. and Bhalla, A. (2011), "Living with offshoring: the impact of offshoring on the evolution of organizational configurations", Journal of World Business, Vol. 46 No. 3, pp. 346-358.

Larsen, M.M., Manning, S.D. and Pedersen, T. (2013), "Uncovering the hidden costs of offshoring: the interplay of complexity, organizational design, and experience", Strategic Management Journal, Vol. 34 No. 5, pp. 533-552.

Lepak, D.P. and Gowan, M. (2010), Human Resource Management: Managing Employees for Competitive Advantage, Pearson, Upper Saddle River, NJ.

Lepak, D.P. and Snell, S.A. (1998), "Virtual HR: strategic human resource management in the 21st century”, Human Resource Management Review, Vol. 8 No. 3, pp. 215-234. 
IJPDLM $47,2 / 3$

Lewin, A.Y. and Couto, V. (2007), Next Generation Offshoring: The Globalization of Innovation, Offshoring Research Network, Duke University, Durham, NC.

Lewin, A.Y. and Peeters, C. (2006), "Offshoring work: business hype or the onset of fundamental transformation?”, Long Range Planning, Vol. 39 No. 3, pp. 221-239.

Lewin, A.Y. and Volberda, H.W. (2011), "Co-evolution of global sourcing: the need to understand the underlying mechanisms of firm-decisions to offshore", International Business Review, Vol. 20 No. 3, pp. 241-251.

Lewin, A.Y. and Zhong, X. (2013), "The evolving diaspora of talent: a perspective on trends and implications for sourcing science and engineering work", Journal of International Management, Vol. 19 No. 1, pp. 6-13.

Lewin, A.Y., Massini, S. and Peeters, C. (2009), "Why are companies offshoring innovation? The emerging global race for talent”, Journal of International Business Studies, Vol. 40 No. 6, pp. 901-925.

Lewin, A.Y., Massini, S., Perm-Ajchariyawong, N., Sappenfield, D. and Walker, J. (2009), "Getting serious about offshoring in a struggling economy", Shared Services News, February, pp. 19-23.

Lewin, A.Y., Perm-Ajchariyawong, N. and Russell, J.W. (2011), "Taking offshoring to the next level: the 2009 Offshoring Research Network Corporate Client Survey report”, The Conference Board Research Report No. R-1473-11-RR, Duke University, Durham, NC.

Luo, Y., Wang, S.L., Jayaraman, V. and Zheng, Q. (2013), "Governing business process offshoring: properties, processes, and preferred modes”, Journal of World Business, Vol. 48 No. 3, pp. 407-419.

Manning, S.D. (2014), "Mitigate, tolerate or relocate? Offshoring challenges, strategic imperatives and resource constraints", Journal of World Business, Vol. 49 No. 4, pp. 522-535.

Manning, S.D., Lewin, A.Y. and Schuerch, M. (2011), "The stability of offshore outsourcing relationships: the role of relation specificity and client control", Management International Review, Vol. 51 No. 3, pp. 381-406.

Manning, S.D., Massini, S. and Lewin, A.Y. (2008), "A dynamic perspective on next-generation offshoring: the global sourcing of science and engineering talent", Academy of Management Perspectives, Vol. 22 No. 3, pp. 35-54.

Manning, S.D., Ricart, J.E., Rosatti Riqué, M.S. and Lewin, A.Y. (2010), "From blind spots to hotspots: how knowledge services clusters develop and attract foreign investment", Journal of International Management, Vol. 16 No. 4, pp. 369-382.

Massini, S., Perm-Ajchariyawong, N. and Lewin, A.Y. (2010), "Role of corporate-wide offshoring strategy on offshoring drivers, risks and performance", Industry and Innovation, Vol. 17 No. 4, pp. 337-371.

Mukherjee, D., Gaur, A.S. and Datta, A. (2013), "Creating value through offshore outsourcing: an integrative framework", Journal of International Management, Vol. 19 No. 4, pp. 377-389.

Nieto, M.J. and Rodríguez, A. (2011), "Offshoring of R\&D: looking abroad to improve innovation performance”, Journal of International Business Studies, Vol. 42 No. 3, pp. 345-361.

Ørberg Jensen, P.D., Larsen, M.M. and Pedersen, T. (2013), "The organizational design of offshoring: taking stock and moving forward", Journal of International Management, Vol. 19 No. 4, pp. 315-323.

Paz-Aparicio, C. and Ricart, J.E. (2013), “Offshoring activities impact a company's business model: the case of BBVA and Banco Santander", in Pedersen, T., Bals, L., Ørberg Jensen, P.D. and Larsen, M.M. (Eds), The Offshoring Challenge: Strategic Design and Innovation for Tomorrow's Organization, Springer, London, pp. 21-35.

Penrose, E.E.T. (1959), The Theory of the Growth of the Firm, Blackwell, Oxford, UK.

Pereira, V. and Anderson, V. (2012), "A longitudinal examination of HRM in a human resources offshoring (HRO) organization operating from India”, Journal of World Business, Vol. 47 No. 2, pp. 223-231.

Pisani, N. and Ricart, J.E. (2016), "Offshoring of services: a review of the literature and organizing framework", Management International Review, Vol. 56 No. 3, pp. 385-424, doi: 10.1007/s11575015-0270-7. 
Prahalad, C.K. and Hamel, G. (1990), "The core competence of the corporation”, Harvard Business Review, Vol. 68 No. 3, pp. 79-91.

Quinn, J.B. (1999), "Strategic outsourcing: leveraging knowledge capabilities", Sloan Management Review, Vol. 40 No. 4, pp. 9-22.

Reichel, A. and Lazarova, M. (2013), "The effects of outsourcing and devolvement on the strategic position of HR departments", Human Resource Management, Vol. 52 No. 6, pp. 923-946.

Roza, M., Van den Bosch, F.A.J. and Volberda, H.W. (2011), "Offshoring strategy: motives, functions, locations, and governance modes of small, medium-sized and large firms", International Business Review, Vol. 20 No. 3, pp. 314-323.

Schmeisser, B. (2013), "A systematic review of literature on offshoring of value chain activities", Journal of International Management, Vol. 19 No. 4, pp. 390-406.

Schumpeter, J.A. (1934), The Theory of Economic Development, Oxford University Press, London.

Shih, H.-A. and Chiang, Y.-H. (2011), "Exploring the effectiveness of outsourcing recruiting and training activities, and the prospector strategy's moderating effect", The International Journal of Human Resource Management, Vol. 22 No. 1, pp. 163-180.

Sidhu, J.S. and Volberda, H.W. (2011), "Coordination of globally distributed teams: a co-evolution perspective on offshoring", International Business Review, Vol. 20 No. 3, pp. 278-290.

Stringfellow, A., Teagarden, M.B. and Nie, W. (2008), "Invisible costs in offshoring services work", Journal of Operations Management, Vol. 26 No. 2, pp. 164-179.

Stroh, L.K. and Caligiuri, P.M. (1998), "Strategic human resources: a new source for competitive advantage in the global arena", The International Journal of Human Resource Management, Vol. 9 No. 1, pp. 1-17.

Tate, W.L. (2014), "Offshoring and reshoring: US insights and research challenges”, Journal of Purchasing and Supply Management, Vol. 20 No. 1, pp. 66-68.

Tate, W.L., Ellram, L.M., Bals, L. and Hartmann, E. (2009), "Offshore outsourcing of services: an evolutionary perspective", International Journal of Production Economics, Vol. 120 No. 2, pp. 512-524.

Tate, W.L., Ellram, L.M., Schoenherr, T. and Petersen, K.J. (2014), "Global competitive conditions driving the manufacturing location decision”, Business Horizons, Vol. 57 No. 3, pp. 381-390.

Ulrich, D. (1998), Delivering Results: A New Mandate for Human Resource Professionals, Harvard Business School Press, Boston, MA.

Williamson, O.E. (1975), Markets and Hierarchies: Analysis and Antitrust Implications, Free Press, New York, NY.

Williamson, O.E. (1993), "Transaction cost economics and organization theory", Industrial and Corporate Change, Vol. 2 No. 2, pp. 107-156.

Wright, P.M. and McMahan, G.C. (1992), "Theoretical perspectives for strategic human resource management”, Journal of Management, Vol. 18 No. 2, pp. 295-320.

Youngdahl, W.E., Ramaswamy, K. and Dash, K.C. (2010), "Service offshoring: the evolution of offshore operations", International Journal of Operations \& Production Management, Vol. 30 No. 8, pp. $798-820$.

\section{Corresponding author}

Carmen Paz-Aparicio can be contacted at: Carmen.Paz@uc3m.es 